\title{
Компетенция судов общей юрисдикции рассматривать предпринимательские споры с участием иностранных лиц в свете нового АПК РФ
}

Муранов А.И. *

Как известно, в СССР все судебные дела по вопросам предпринимательской деятельности с участием иностранных юридических и физических лиц подлежали рассмотрению, по общему правилу, в судах обшей юрисдикции (народных судах). Исключением из этого было рассмотрение дел в порядке третейского производства на основании соглашения сторон или на основании, в частности, Конвенции о разрешении арбитражным путем гражданско-правовых споров, вытекающих из отношений экономического и научно-технического сотрудничества (Москва, 26 мая 1972 г.) ${ }^{1}$, предусматривавшей применительно к внешнеэкономическим спорам их рассмотрение, как правило, в арбитражном суде при торговой палате в стране ответчика или по договоренности сторон в третьей стране - участнице Конвенции (в СССР таким арбитражным судом являлась Внешнеторговая арбитражная комиссия при ТПП СССР). Государственные арбитражи в СССР не являлись судами в строгом смысле этого слова, а их задачей было только рассмотрение споров между государственными хозяйствуюшими организациями.

Особенности рассмотрения дел в государственном арбитраже были настолько серьезны, а незнание государственными арбитрами специфики разрешения предпринимательских споров с участием иностранных лиц настолько велико, что при преврашении в России в 1991 г. государственного арбитража в систему арбит-

* Муранов Александр Игоревич - к.ю.н., доцент кафедры международного частного и гражданского права МГИМО (У) МИД России (www.muranov.ru).

' Ратифицирована Верховным Советом СССР 15 мая 1973 г. (Ведомости Верховного Совета СССР. - 1973. - № 18. - Ст. 227). Вступила в силу 13 августа 1973 г. 
ражных судов² было решено не делать споры с участием иностранных лиц и организаций с иностранными инвестициями подведомственными, по обшему правилу, государственным арбитражным судам: статья 20 АПК РФ $1992 \Gamma{ }^{3}$ предусматривала, что « $A p$ битражиюлу суду подведомствениы экономические споры меэлу организацияли, гразсданами-предпринимателями, находящимися на мерритории Российской Федерачии ...

Арбитражсному суду подведомствениы споры межуду организациями, гражсданами-предпринимапелями, когда одна из сторон иаходится иа перритории другого государства, если это предусмотрено межгосударствениыл соглашением, международньм договором или соглаитением сторон.

Арбитражснолу суду подведомственны также споры организаций с иностранными инвестициями, если это предусмотрено межгосударственныл соглашением или соглашением сторон».

Таким образом, до 1995 г. согласно российскому законодательству компетентными разрешать предпринимательские споры с участием иностранных лиц являлись, по общему правилу, суды общей юрисдикции (за исключением случаев, когда стороны договаривались о передаче спора в государственный арбитражный суд, равно как и за исключением случаев, предусмотренных международными договорами РФ: последние были заключены только в рамках СНГ и касались споров субъектов из стран - участниц СНГ).

Однако в 1995 г. вступил в силу второй АПК РФ, согласно пункту 6 статьи 22 которого государственные арбитражные суды обрели компетенцию рассматривать подведомственные им дела с участием иностранных лиц ${ }^{4}$ и организаций с иностранными инвестициями. Наделение их такой компетенцией было одним из важнейших этапов в процессе борьбы между государственными арбитражными судами и судами общей юрисдикции в борьбе за юрисдикционную компетенцию. Такая борьба вполне объяснима:

2Закон РФ от 4 июля 1991 г. «Об арбитражном суде» (Ведомости Съезда народных депутатов РСФСР и Верховного Совета РСФСР. - 1991. - № 30. - Ст. 1013. В Закон были внесены изменения 24 июня 1992 г. и 7 июля 1993 г.).

${ }^{3}$ Ведомости Съезда народных депутатов Российской Федерации и Верховного Совета Российской Федерации. - 1992. - № 16. - Ст. 836.

${ }^{4}$ Под ними далсе будут пониматься, если из контекста не будет следовать иное, осуществляющие предприниматсльскую деятельность иностранные организации, международные организации, иностранные граждане, лица без гражданства. 
с момента, когда в России возник не материально-правовой дуализм в сфере экономического оборота, а юрисдикционный, две ветви судебной системы неизбежно должны были вступить в конкуренцию: Est boni judicis ampliare jurisdictionem ${ }^{5}$.

Подобная конкурируюшая юрисдикция не могла не породить с первых же дней многочисленные проблемы разграничения компетенции, которые явились причиной появления Постановления Пленума Верховного Суда РФ и Пленума Высшего Арбитражного Суда РФ от 18 августа 1992 г. № 12/12 «О некоторых вопросах подведомственности дел судам и арбитражным судам»' . Данным Постановлением острота проблемы подведомственности была, в основном, снята, хотя и по сей день в правоприменительной практике часто возникают вопросы разграничения компетенции между судами, причем зачастую они являются не чем иным, как проявлением того, что можно было бы назвать «борьбой за юрисдикцию» (или же, в ряде случаев, «соревнованием в нежелании рассмотреть спор»). В целом же можно утверждать, что в упомянутой «борьбе» преимушество имели и имеют государственные арбитражные суды. При этом законодательное расширение компетенции государственных арбитражных судов в 1995 г. за счет предоставления им права рассматривать споры с участием иностранных лиц и организаций с иностранными инвестициями стало одним из решаюших факторов на пути получения такого преимущества. Однако, в отличие от «внутренних» споров, государственные арбитражные суды столкнулись в этой сфере с явно выраженным стремлением Верховного Суда РФ сохранить за судами общей юрисдикции компетенцию рассматривать экономические споры с участием иностранных лиц. Так, в своем определении от 28 октября 1996 г. Судебная Коллегия Верховного Суда РФ указала: «Нельзя согласиться с доводами экалобы о том, что данная категория споров подведомственна лишь арбитражсному суду. Действительно, согласно п. $6 \mathrm{~cm} .22$ Арбитразнного прочессуального кодекса $Р \Phi$, арбитражный суд рассматривает подведомствениье ему дела с участием организаций и граждан Российской Федерации, а также иностранных организачий, организауий с иностраннымии инвестичиями, межсународных организаций, иностранных граждан,

${ }^{5}$ Хороший судья должсн понимать свою юрисдикцию расширительно (лап1.).

${ }^{6}$ Бюллетснь Верховного Суда Российской Федерации. - 1992. - № 11. - С. 9-10. 
лич без гражданства, осуцествляючих предпринимательскую деятельность. Однако в соответствии со ст. 25 ГПК РСФСР споры с участием иностраниых граждан, лич без гражданства, иностранныхх предприятий и организачий подведомственны такэсе и судам общей юрисдикции. Поэтому споры с участием иностранных предприятий и организаций могут рассматриваться как в судах общей юрисдикции, так и в арбитражсых судах»? . Более того, в данном деле Верховный Суд РФ использовал расширительное толкование статьи 25 ГПК РСФСР: хотя в ней говорится только об иностранных гражданах, лицах без гражданства, иностранных предприятиях и организациях, она была применена в отношении дела, в котором иск был заявлен в суд обшей юрисдикции организацией с иностранными инвестициями.

Сказанное демонстрирует правильность следующего тезиса: любая организованная система стремится конкурировать с аналогичными системами и доминировать над ними, ведь от этого во многом зависят условия ее сохранения.

Верховный Суд РФ отстоял на тот момент компетенцию судов общей юрисдикции рассматривать споры с участием иностранных лиц и организаций с иностранными инвестициями, ввиду чего в России возникла конкурируюшая юрисдикция в отношении предпринимательских споров с участием таких лиц. Очень часто это умело использовалось субъектами торгового оборота в своих целях, в том числе сомнительных (о чем свидетельствует история с обрашением в Черемушкинский межмуниципальный суд г. Москвы иностранного юридического лица с иском, преследуюшим цель получения контроля над НТВ). То обстоятельство, что суды общей юрисдикции сохранили за собой компетенцию рассматривать споры с участием иностранных лиц и организаций с иностранными инвестициями, объяснялось во многом тем, что Федеральный закон от 5 мая 1995 г. № 71-Ф3 «О введении в действие Арбитражного процессуального кодекса Российской Федерации» ${ }^{8}$ не предусматривал норм, согласно которым: 1) с момента введения АПК РФ 1995 г. в действие утрачивали бы силу положения других законов, устанавливающих подведомственность, в части, противоречашей АПК РФ 1995 г.; 2) законы и иные нормативные правовые

${ }^{7}$ Бюллетень Верховного Суда Российской Федерации. - 1997. - № 7. - С. 2.

${ }^{8}$ Собрание законодательства Российской Федерации. - 1995. - № 19. - Ст. 1710. 
акты применялись бы только в части, не противоречащей АПК РФ 1995 Г.

После вступления в силу АПК РФ 1995 г. «борьба за юрисдикцию» развернулась с новой силой и с очень любопытными нюансами в отношении компетенции разрешать вопросы приведения в исполнение иностранных решений ${ }^{9}$. И хотя с точки зрения действующего законодательства, доктрины и юридической логики претензии государственных арбитражных судов на обладание такой компетенцией были неосновательными, в практическом плане они добились желаемого и de lege ferenda это казалось вполне естественным.

«Борьба за юрисдикцию» продолжилась также и в отношении компетенции рассматривать споры с участием иностранных лиц и организаций с иностранными инвестициями. В итоге был принят Арбитражный процессуальный кодекс РФ от 24 июля 2002 г. № 95-Ф3 ${ }^{10}$, пункт 5 статьи 27 которого аналогичен пункту 5 статьи 22 АПК РФ 1995 г. и устанавливает, что «Арбитражные суды рассматривают подведомствениье им дела с участием российских организаций, граждан Российской Федерации, а также иностранных организачий, мељсународных организауий, иностранных граждан, лич без гражданства, осуществляючих предпринимательскую деятельность, организауий с иностранньми инвестичиями, если иное не предусмотрено мелкдународньм договором Российской Федерации». При этом недочет, совершенный в 1995 г., был исправлен и Федеральный закон от 24 июля 2002 г. № 96-Ф3 «О введении в действие Арбитражного процессуального кодекса Российской Федерации» предусмотрел: “Статья 3. Федеральные законы и иные нормативные правовые акты, действуючие иа территории Российской Федерачии и связанные с Арбитражсным прочессуальиым кодексом Российской Федерации, подлељсат приведению в соответствие с Арбитражсным прочессуальным кодексом Российской Федерации.

Впредь до приведения в соответствие с Арбитражным процессуальным кодексом Российской Федерации указанные федеральные законыл и иные нормативные правовые акты, а такље Указ Президиу-

${ }^{9}$ Муранов А.И. Исполнение иностранных судебных и арбитражных решений: компетенция российских судов. - М.: Юридический Дом «Юстицинформ», 2002. $168 \mathrm{c}$.

${ }^{10}$ Собрание законодательства Российской Федерации. - 2002. - № 30. - Ст. 3012. 
ма Верховного Совета СССР от 21 июия 1988 года № 9131-XI «O признании и исполнении в СССР решений иностранных судов и арбитражей» с момента введения в действие настоящим Федеральным законом Арбитражсного прочессуального кодекса Российской Федерачии применяются в части, не противоречащей Арбитражному прочессуальному кодексу Российской Федерачии. ...

Статья 6. Ввести в действие 1 «Подведомственность» главы 4 Арбитражсиого прочессуального кодекса Российской Федерачии через десять дней со дня его официальиого опубликования.

С этого момента утратаниают силу кщатья 22 «Подведомственность дел" Арбитражкного процессуальіого кодекса Российской Федерации (Собрание законодательства Российской Федерачии, 1995, № 19, ст. 1709), а также положения других федеральных законов, устанавливающих подведомственность, в части, противоречащей Арбитражному прочессуальному кодексу Российской Федерачии.

Статья 7. Дела, которые находятся в производстве судов общей юрисдикции и которые в соответствии с Арбитражсным прочессуальиым кодексом Российской Федерачии отнесены к подведомственности арбитражсных судов, в течение двух недель со дня введения в действие 1 "Подведомственность» главы 4 Арбитражсного прочессуального кодекса Российской Федерачии с согласия истиов передапотся судами общей юрисдикции на основании определения суда в арбитражсные суды в соответствии с правилами подсудности, установленными Арбитражным прочессуальным кодексом Российской Федерации и действующими на момент передачи дела.

Если истеи не согласен на передачу его дела судом общей юрисдикчии в арбитражный суд, суд общей юрисдикции прекращает производство по данному делу в связи с иеподведомственностью дела суду общей юрисдикции».

В условиях наличия таких норм Верховный Суд РФ уже не может безапелляционно ссылаться на то, что в соответствии со ст. 25 ГПК РСФСР споры с участием иностранных граждан, лиц без гражданства, иностранных предприятий и организаций являются подведомственными также и судам общей юрисдикции и что ввиду этого споры с участием иностранных лиц могут рассматриваться как в судах общей юрисдикции, так и в арбитражных судах. 
Но является ли это однозначным доказательством того, что периоду конкурируюшей юрисдикции в отношении предпринимательских споров с участием иностранных лиц пришел конец? Думается, что ответ полностью положительным быть не может. Вопервых, разграничение подведомственности, базирующееся на природе споров, урегулировано в российском праве еще не до конца четко и определенно. Между новым АПК РФ 2002 г. и старым ГПК РСФСР в этом плане имеются некоторые нестыковки, а проблемы толкования положений этих нормативных актов могут оказаться настолько запутанными, что обращение к правилам Федерального закона от 24 июля 2002 г. № 96-Ф3 «О введении в действие Арбитражного процессуального кодекса Российской Федерации» не окажется панацеей.

Но если исходить только из разграничения подведомственности споров, базируюшегося на их природе, то не имеет никакого значения, участвует ли в деле российское лицо или же иностранное. В силу действия на территории России в процессуальной сфере принципа национального режима это означает, что в тех случаях, когда российские лица должны будут обращаться именно в государственные арбитражные суды, туда же должны будут обращаться в аналогичных ситуациях и иностранные лица, а в тех случаях, когда российским лицам будет надлежать обращаться в суды общей юрисдикции, иностранные лица должны будут в похожих ситуациях обрашаться в них же.

Однако только что сказанное верно в отношении тех случаев, когда иностранные лица являются истцами. Когда же они выступают ответчиками, то одного разграничения подведомственности, базируюшейся на природе споров, не будет являться достаточным.

В самом деле, хотя конкретный спор может по своей природе быть принципиально подведомственным какому-то российскому государственному суду, и иностранное лицо могло бы выступать в нем в качестве ответчика, однако в силу того, что в данном конкретном споре будет отсутствовать юрисдикционная привязка, присутствие которой является необходимым основанием наличия у российского государственного суда компетенции рассматривать спор, такой суд рассмотреть спор, при всем своем желании, не сможет. Примерами таких юрисдикционных привязок являются ука- 
зываемые в пункте 1 статьи 247 АПК РФ 2002 г. обстоятельства: "Арбитражсные суды в Российской Федерации рассматривают дела по экономическим спорам и другие дела, связанные с осуществлением предпринимательской и иной экономической деятельности, с участием иностранных организауий, международных организаций, иностранных граждан, лич без гражданства, осуществляющих предпринимательскую и иную экономическую деятельность (далее иностранные лица), в случае, если:

1) ответчик находится или проживает на территории Российской Федерачии либо на территории Российской Федерачии находится имучество ответчика;

2) орган управления, филиал или представительство иностранного лица находится на территории Российской Федерачии;

3) спор возник из договора, по которому исполнение должсно иметь место или имело место на территории Российской Федерауии;

4) требование возникло из причинения вреда имуществу действием или иным обстоятельством, имевиими место на территории Российской Федерачии или при наступлении вреда на территории Российской Федерачии;

5) спор возник из неосновательного обогачения, имевщего место на территории Российской Федерачии;

6) истеч по делу о зачите деловой репутации находится в Российской Федерачии;

7) спор возник из отношений, связанных с обращением ченных бумаг, выпуск копорых имел место на территории Российской Федерачии;

8) заявитель по делу об установлении факта, имеюоего торидическое зиячение, указывает на иаличие этого факта на территории Российской Федерачии;

9) спор возник из отношений, связанных с государственной регистрачией имен и других объектов и оказанием услуг в межжународной ассоциауии сетей "Интернет» на территории Российской Федерации;

10) в других случаях при наличии тесной связи спорного правоотночения с территорией Российской Федерации».

Соответственно, институт разграничения подведомственности споров имеет абсолютную значимость исключительно в отноше- 
нии внутренних споров. Когда же речь заходит о спорах с участием иностранного лица как ответчика, то разграничение подведомственности перестает быть самодостаточным и возникает необходимость обрашения к вопросам подсудности, причем не только внутринациональной (внутритерриториальной), но и международной. "Термин «подсудность» употребляется в различном смысле: им обозначается не только распределение компетенции между судами данной судебной системы, но и свойства или признаки, по которым дела отнесены к компетенции данного суда... В этом смысле термин «подсудность» применяется и для обозначения (тем самьм ограничения) компетенчии судов определенной страны (компетенции ее судебного аппарата) при рассмотрении ими дел с иностранньмм элементом»" ${ }^{11}$.

Из сказанного вытекает, что применительно к компетенции российских судов общей юрисдикции рассматривать предпринимательские споры с участием иностранных лиц необходимо помнить не только о вопросах подведомственности, но и о вопросах подсудности, в том числе международной. Между тем, Федеральный закон от 24 июля 2002 г. № 96-Ф3 «О введении в действие Арбитражного процессуального кодекса Российской Федерации» в своих статьях 6 и 7 предусмотрел приоритет АПК РФ 2002 г. над ГПК РСФСР и другими законами только в отношении вопросов подведомственности, но не подсудности, что немаловажно.

В связи с этим возникает следующий вопрос: возможны ли ситуации, когда как государственный арбитражный суд, так и суд общей юрисдикции в силу только одного статуса лица как иностранного субъекта смогут, основываясь на аспекте международной подсудности вне связи с вопросом о подведомственности спора, претендовать на одновременное наличие у каждого из них компетенции разрешать предпринимательский спор с участием такого иностранного лица?

Представляется, что ответ на такой вопрос должен быть отрицательным. Возможность одновременного признания государственным арбитражным судом и судом общей юрисдикции своей компетенции разрешать предпринимательский спор с участием иностранного лица предполагает наличие таких юрисдикционных

"Луии, Л.А., Марьичева Н.И. Курс международного частного права. Международный гражданский процесс. - М.: Юридическая литература, 1976. - С. 61-62. 
привязок, которые в глазах lex fori допускали бы признание спора международно-подсудным каждому из таких судов. Но в таком случае автоматически вставала бы проблема подведомственности: коль скоро с точки зрения норм о подсудности спор с участием иностранного лица может быть рассмотрен в любом из двух судов, то необходимо выяснить природу спора для передачи его в суд по подведомственности. Ввиду этого в такой ситуации не имеет значения, будет ли являться иностранное лицо истцом или ответчиком.

Oтвет на поставленный выше вопрос мог бы быть и положительным, не будь приняты статьи 3,6 и 7 Федерального закона от 24 июля 2002 г. № 96-Ф3 «О введении в действие Арбитражного процессуального кодекса Российской Федерации». В свете их положений, направленных на недопущение конкурирующей юрисдикции по предпринимательским спорам, ничто в АПК РФ 2002 г. и ГПК РСФСР не позволяет считать, что иностранное лицо будет иметь возможность являться участником предпринимательского спора как в государственном арбитражном суде, так и в суде общей юрисдикции, только благодаря ссылке на свой статус иностранного субъекта. Если в конкретной ситуации такое лицо сможет обеспечить свое участие в разбирательстве по аналогичным делам в различных судах, то это будет означать, прежде всего, что судами было допущено неправильное применение норм о подведомственности.

Более интересен следуюший вопрос: возможны ли ситуации, когда суд общей юрисдикции в силу только одного статуса лица как иностранюго субъекта сможет, основываясь на аспекте международной подсудности вне связи с вопросом о подведомственности спора, претендовать на наличие у него компетенции разрешать предпринимательский спор с участием такого иностранного лица? При этом отвлечемся от моментов, связанных с тем, в каком суде такие споры могут быть рассмотрены более эффективно, о том, каким образом те или иные суды могут использоваться в недобросовестных целях и т.д.: к собственно праву это отношения не имеет.

Итак, обратимся к рассмотрению не проблемы того, какое значение имеет сущность спора, а проблемы того, может ли наличие юрисдикционной привязки, признаваемой российским процессуальным правом, обусловливать компетенцию суда общей юрис- 
дикции разрешать предпринимательский спор с участием иностранного лица безотносительно к вопросу о подведомственности такого спора? Для большей простоты будем исходить из того, что предпринимательский спор с участием иностранного лица носит исключительно гражданско-правовой характер и рассматривается в порядке искового производства в федеральных районных судах обшей юрисдикции (и приравненных к ним), а не мировыми судьями ${ }^{12}$.

Элементарный анализ показывает, что в том конкретном случае, когда в споре будет фигурировать конкретная юрисдикционная привязка, предусматриваемая как процессуальным законом, регулируюшим деятельность судов общей юрисдикции (т.е. ГПК РСФСР), так и процессуальным законом, регулируюшим деятельность государственных арбитражных судов (т.е. АПК РФ 2002 г.), без обращения к анализу вопроса о подведомственности такого спора обойтись будет невозможно. Если благодаря наличию данной юрисдикционной привязки право рассматривать такой спор с точки зрения международной подсудности будет иметься одновременно и у суда общей юрисдикции, и у государственного арбитражного суда, то необходимо будет решать вопрос о подведомственности спора. Отсюда следует, что сама принципиальная постановка приведенного выше вопроса допустима только применительно к тому случаю, когда процессуальный закон, регулируюший деятельность судов обшей юрисдикции (т.е. ГПК РСФСР), будет предусматривать такую юрисдикционную привязку, которая не будет предусмотрена процессуальным законом, регулируюшим деятельность государственных арбитражных судов (т.е. АПК РФ 2002 г.). В результате окажется, что даже если дело по своей природе является подведомственным государственным арбитражным судам, то ввиду того, что ни одно из обстоятельств, в нем фигурирующих, не может быть квалифицировано как признаваемая АПК РФ 2002 г. юрисдикционная привязка, оно, с точки зрения института международной подсудности, не может быть в них передано. Но поскольку одно из обстоятельств, фигурирую-

\footnotetext{
12 Однако не следует забывать, что некоторые споры, рассматриваемые в судах общей юрисдикции и государственных арбитражных судах, могут иметь полностью или частично административную природу и рассматриваться не в порядке искового производства. У таких дел может иметься специфика, которую необходимо учитывать отдельно.
} 
щих в деле, будет квалифицировано как признаваемая ГПК РСФСР юрисдикционная привязка, то будет ли это означать, что такое дело может быть рассмотрено судом, компетентным с точки зрения института международной подсудности, хотя оно ему по своей природе не является подведомственным? На это можно взглянуть и с точки зрения лица, претендующего на защиту своих прав: в том случае, когда из-за отсутствия юрисдикционной привязки дело не может быть рассмотрено государственным арбитражным судом, то почему оно не может быть в целях защиты прав такого лица быть разрешено в суде общей юрисдикции, компетентном с точки зрения закрепленных в ГПК РСФСР норм института международной подсудности, хотя оно ему и неподведомственно?

Но прежде резонно спросить: а ГПК РСФСР вообще предусматривает ли юрисдикционные привязки, которые не указаны в АПК РФ 2002 г.?

Как известно, в ГПК РСФСР специальные юрисдикционные привязки не предусмотрены. Его статья 434-1 предлагает обратиться для их определения к правилам внутренней подсудности: «Подсудность судам РСФСР гражданских дел по спорам, в которых участвуют иностранные гразкдане, лица без гражсданства, иностранные предприятия и организачии, а также по спорам, по которым хотя бы одна из стороп прожсивает за грапицей, определяется ... исходя из правил подсудности, установлениых иастояцим Кодексом». Такими правилами являются следуюшие (далее приводятся только те из них, которые могут иметь отношение к спорам предпринимательского характера): «Иск предъявляется в суде по месту жительства ответчика. Иск к юридическому лицу предъявляется по месту иахождения органа или имущества юридического лица» (статья 1 17); "Иск к ответчику, место жительства которого неизвестно, мохсет быть предъявен по месту иахождения его имущества или по последиему известиому месту его жсительства.

Иск к отвепчику, не имеючену в СССР места жсительства, может быть предъявлен по месту пахождения его имущества или по последнему известному месту его жсительства в СССР.

Иск, вытекаючий из деятельности филиала юридического лича, может быть предъявлен также по месту нахождения филиала. ...

Иски о возмецении вреда, причиненного имуществу гражданина или юридиеского лица, могут предъявляться пакже по месту причинения вреда. 
Иски о возмецении убытков, причинениых столкновением судов, а также о взыскании вознаграждения за оказание помочи и спасеиие на море могут предвявляться такэе по месту нахождения судна ответчика или порта приписки судна.

Иски, вытекаючиие из договоров, в которых указано место исполнения, могут быть предъявлены также по месту исполнения договора. ...

Выбор межсду несколькими судами, которым согласно настоящей статье подсудно дело, принадлежсит истиу» (статья 118); “Иски о праве на строение, об освобожсдении илуцщества от ареста, об установлении порядка пользования земельным участком подсудиы суду по месту нахождения имуцества или земельного участка. ...

Иски к перевозчикам, вытекаючие из договоров перевозки грузов, пассажиров или багажса, предъявляются по месту иахождения управления транспортной оргапизации, к которой в установленном порядке была предълвлена претензия. ...» (статья 119); “Стороны могут по соглаиению мезсду собой изменить территориальную подсудность для данাюого дела.

Подсудность, установленная статьей 119 настоящего Кодекса, не может быть изменена соглашением сторон» (статья 120). Кроме того, статья 121 ГПК РСФСР предусматривает: «Иск к нескольким ответчикам, прожсиваючим или находяцимся в разных местах, предъявляется по месту жительства или месту нахождения одного из ответчиков по выбору истча.

Встречный иск независимо от его подсудности предъявляется в суде по месту рассмотрения первоначального иска.

Гражданский иск, вытекающий из уголовного дела, если ои не был заявлен или не был разрешен при производстве уголовного дела, предъявляется для рассмотрения в порядке граэданского судопроизводства по правилам о подсудности, установлениым настояиим Кодексом». В связи с последней нормой необходимо также вспомнить пункт 10 статьи 31 Уголовно-процессуального кодекса РФ от 18 декабря 2001 г. № 174-Ф3, согласно которому «Подсудность гражданского иска, вытекающего из уголовного дела, определяется подсудностью уголовного дела, в котором он предъявлен» (по обшему правилу, уголовное дело подлежит рассмотрению в суде по месту совершения преступления (пункт 1 статьи 32 Уголовно-процессуального кодекса РФ от 18 декабря 2001 г. № 174-Ф3)). 
Если обратиться к статьям 35 - 38 АПК РФ 2002 г. $^{13}$, устанавливаюшим правила подсудности, то можно обнаружить, что они по-

${ }_{13}$ «Иск иредъявляется в арбитражсный суд субъекпа Российской Федерации по лесту нахождепия или месту жсительспва опвепчика" (статья 35); "I. Иск к омветчику. леспо нахождения или жеспо жительспва которого неизвестно, можст быть предъявлен в арбитиражиый суд по леспу нахождения его имуццества либо по его последиему извеспноиу несту иахождения или иесту жительства в Российкой Федераıиıи.

2. Иск к опвемчикан, иаходяицияся или проживаюиции иа перрипориях разных суб́ъектов Российской Федерации, предъявляепся в арбитражный суд по месту нахождения ипи месту жипельства одного из опвепииков.

3. Иск к опветчику, находяцемуся или проживаючему на территории иностранного государспва, ножет быпь предъявлен в арбитражный суд по жесту нахождения на террипории Российской Федерации илуцества омвспичка.

4. Иск, выпекаюицй из договора, в копюром указано место его исполнения, может быть предъявлен также в арбитражный суд по месту исполиения договора.

5. Иск к юридичсколу лицу, выпекаюиий из деятельности его филиала, иредспавительства, расположенных вне места нахождения юридического лица, льжет быпь предъявлен в арбитражный суд по меспу иахождения юридического лича или его филиала, представипельства.

6. Иски о возиеијении убыпков, причинениых столкновениел судов, взыскании вознаграждения за оказание полоии и спасание на море могут предвявляться в арбитражный суд по жеспу иахождения судиа опвемиика или порпа приписки судна ответика либо по меспу причинения убипиков.

7. Выбор межуу арбитражными судами, которым согласно настояијей статье подсудно дело, иринадлежит испиу" (спапья 36); "Подсудность, успановлениая спатьяни 35 и 36 иаспояиего Кодекса, жожеп быпи изненена по соглаитиио сторон до принятия арбитражсным судом заявления к своену производству» (статьяя 37); "1. Иски о правах на иедвижниое ижуијество предъявляются в арбитражньй суд по несту нахолсдения эмого имуцества.

2. Иски о правах на морские и воздуишые суда, суда внупреннего плавания, космические объекпы предъяеляются в арбитражный суд по месту их государспвенной региспрации.

3. Иск к перевозчику, вытекапицй из договора перевозки грузов, пассажсиров и их багажа, в пои иисле в случае, если перевозчик является одним из отвепчиков, предъявляепся в арбитражы й суд по месту нахождения перевозчика. ...

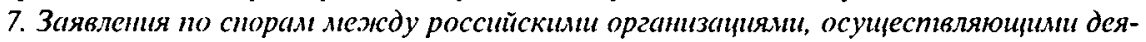
пельность или имеюицини инуиество на территории иностранного государства. подаются в арбитражсиый суд по Ансту государствениой регистрации на перриmopuu Poccul̆ckoù Фedepalıu opzanuзalıuı-omвenчuka.

Заявлсния по спорам межсуу российскими организациями, осуијествляюицими деяпельность или инеюициии имууцеспво на перритории иностранного государспва и ие инеюициии государственной регистрации на перритории Российской Федераиии, подаются в Арбитражсиый суд Московской области. ...

10. Вспречиьй иск независицо оп его подсудности предъявляепся в арбитражный суд по неспу рассмопрения первоначального иска» (статья 38). 
вторяют правила о подсудности в ГПК РСФСР, за исключением следуюших положений: иск к юридическому лицу предъявляется по месту нахождения органа или имушества юридического лица (статья 117 ГПК РСФСР); иск к ответчику, не имеющему в СССР места жительства, может быть предъявлен по последнему известному месту его жительства в СССР (статья 118 ГПК РСФСР); иски о возмещении вреда, причиненного имушеству гражданина или юридического лица, могут предъявляться также по месту причинения вреда (статья 118 ГПК РСФСР) ${ }^{14}$. ВПолне понятно, что в АПК не имеется и нормы о том, что подсудность гражданского иска, вытекающего из уголовного дела, определяется подсудностью уголовного дела, в котором он предъявлен.

Однако в отношении положений о том, что иск к юридическому лицу предъявляется по месту нахождения органа или имущества юридического лица (статья 117 ГПК РСФСР) и что иски о возмещении вреда, причиненного имушеству гражданина или юридического лица, могут предъявляться также по месту причинения вреда (статья 118 ГПК РСФСР), необходимо отметить один очень важный нюанс. Дело в том, что приведенные выше положения статьи 35 - 38 АПК РФ 2002 г. не содержат юрисдикционных привязок в собственном смысле этого понятия (исключением является только пункт 3 статьи 36 АПК РФ 2002 г.): они предусматривают правила подсудности, рассчитанные, прежде всего, на использование во внутринациональном российском обороте. Юрисдикционные же привязки содержатся в АПК РФ 2002 г. в статьях 247 $249^{15}$. При этом подпункты 1 и 4 статьи 247 содержат положения,

${ }^{14}$ Незначительная разница в формулировках норм об исках к перевозчикам может не приниматься во внимание, поскольку они по своей сути совпадают.

${ }^{15}$ "l. Aрбитражсные суды в Российской Федераиии расслатривают дела по экономическим спорам и другие дела, связанные с осуицествлением предпринилательской и иной экономической деятельности, с участием иноспранных организаций, международных организаций, иностраниых граждан, лиц без гражданспва, осуицествляюици иредприпинапельскую и иную эконолическую деятельность (далее - иностраниые лица), в случае, если:

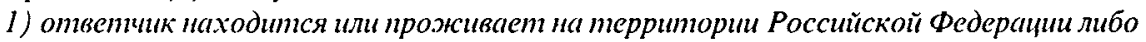
на mерриmории Российской Федерации находипся ииуцество отвемиика;

2) орган управления, филиал или представительство иностранного лица иаходится на meppumopuи Poсcuйской Федераиии;

3) спор возник из договора, по которому исполнение должсио иметь место или имело место на mеррumopuи Pоссийской Федерации; 
подобные приведенным в начале настоящего абзаца. Однако полностью равнозначными последним эти правила АПК РФ 2002 г. признаны быть не могут. Дело в том, что хотя статьи $247-249$ АПК РФ 2002 г. и определяют посредством юрисдикционных привязок компетенцию государственных арбитражных судов в аспекте международной подсудности, они не совсем четко регулируют вопрос о том, в какой именно из государственных арбитражных судов России должен подаваться иск с точки зрения разграничения внутритерриториальной компетенции между ними. Для более четкого определения ответа на такой вопрос возможно два подхода: 1) для разграничения внутритерриториальной компетенции между государственными арбитражными судами России в целях реализации статей 247 - 249 АПК РФ 2002 г. следует руководство-

4) требование возникло из причинения вреда ияниееству действием или иньм обстоятельство.и, ияевиитын место на территории Российской Федерации или при наступлени вреда на mерритории Российской Федерации;

5) спор возикк из неосновательного обогацения, иневиего место на территории Pоссийской Федераиии;

6) истеи по делу о заиците деловой репупиации находится в Российской Федерации;

7) спор возник из опиоиений, связанных с обрацением цениых бумаг, вытуск которых инел лесто на mерритории Российской Федерации;

8) заявитель по делу об установлении факта, имеюицего оридическое значение, указывает иа наличие эмого факта на перритории Российской Федераџии;

9) спор возник из опноцений, связаниых с государственной регистрацией имен и других обиекпов и оказанием услуг в международной ассоџиаци сетей «Иитернет"» на территории Российской Федерации;

10) в других случаях ири наличии тесной связи спорного правоотнотиения с мерриторией Российской Федераıииu.

2. Арбитражние суды в Российской Федерации рассмапривают также экономические споры и другие дела, связанные с предприпияательской и иной экономической деятельностьн с участиен иностраниых лич и отнесениые в соответствии со спатьей 248 настояцего Кодекса к их исключительной колметенции.

3. Арбитражсиье суды в Российской Федерации рассмапривают также дела в соответствии с соллаитением сторон, заключениым по правилам, установленныл стапьей 249 настониего Кодекса.

4. Дело, принятое арбитражным судол к своену рассмотрению с соблюдением правил, предусмотрениых иастояијей статьей, долэсио быпьь рассмотрено ия по суиеству, хопя бо в ходе производства по делу в связи с изиенениен места нахожде-

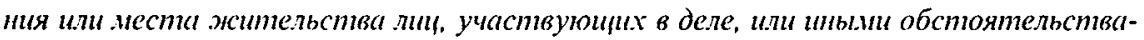
sй оно стапеп опносипься к колиетеници иноспранного суда» (статья 247); «I. К исключительной коипетенци арбитражсиьх судов в Российской Федераиии по делам с участием иностраниьх лиц опносяпся дела: 
ваться правилами подсудности, содержашимися в статьях 35 - 38 АПК РФ 2002 г.; 2) внутритерриториально компетентным арбитражным судом должен быть признан тот, на территории осуществления полномочий которого имело место обстоятельство, указанное в качестве юрисдикционной привязки: в частности, нахождение на территории России органа управления, филиала или представительства иностранного лица, нахождение на территории России места исполнения договора, факт неосновательного обогащения на территории России и т.д. Первый подход вполне реализуем в тех случаях, когда ответчиком в деле выступает российское лицо. В таком случае компетенция государственных арбитражных судов в аспекте международной подсудности будет определяться статьями 247 - 249 АПК РФ 2002 г., а вопросы внут-

1) по спорам в отиоиении находящегося в государственной собственности Российской Федерации имуцеества, в тол числе по спорам, связаниыль с приватизацией государственного имуцествва и принудительным отчуждением ияуцества для государственных нужд;

2) по спорам, преднетоли которых являются недвиясияое инуијество, если пакое инуцество находится на территории Российской Федераџии, или права на него;

3) по спорая, связанньци с регистрацией или выдачей патентов, регистрачией и выдячей свидетельств на поварные знаки, промыниленные образцы, полезиые модели или регистрацией других прав на результаты интеллекпуальной деятельноспи, которые требуют регистрации или выдачи патента либо свидетельства в Российской Федерации;

4) по спораяи о признании недействительнылии записей в государственные реестры (регистры, кадастры), произвсденных компетентныли органом Российской Федерации, ведуции такой реестр (регистр, кадастр);

5) по спорам, связанныл с учреждением, ликвидаџией или регистраџией на террипории Российской Федерации юридических лии и индивидуальных предпринимателей, а также с оспариванием рецкний органов эмих юридических лиц.

2. В исключительной компепенции арбитражньх судов в Российской Федерации иаходятся пакже иредусмотренные в разделе III настояцего Кодекса дела с учаспиел иностраниылх лиц, возиикаючце из адлинистрапивных и иных публичных правоотноиєенйі" (статья 248); «1. В случае, если стороны, хомя бы одна из копорых является иностраниыл лицол, заключили соглаиение, в котороли определили, что арбитражньй суд в Российской Федерации обладает компетенцией по рассмотренио возникичего или могуцего возникнуть спора, связанного с осуццествлением ияи предпринизательской и иной экономической деятельности, арбитражньй суд в Российской Федераџии будет обладапьь исключительиой компетсицией по рассмотрению даниого сиора при условии, что такое соглаиение не изменяет исключительиую компетенцин иностранного суда.

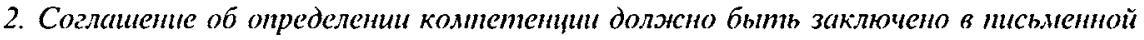
формем (статья 249). 
ритерриториальной подсудности будут решаться согласно статьям 35 - 38 АПК РФ 2002 г. Казалось бы, то, что следует использовать именно первый подход, подтверждается пунктом 2 статьи 254 АПК РФ 2002 г. («Ииостранные лича имеют право обрачуаться в арбитражиые суды в Российской Федерации по правилам подведомственности и подсудности, установленньм настоячим Кодексом, для зациты своих иарученных или оспариваемых прав и законных интересов в сфере предпринимательской и иной экономической деятельности»). Однако смысл данной нормы иной: она не более чем закрепляет принцип национального режима.

Ввиду этого все же думается, что более правильным было бы использование второго подхода, поскольку первый не может быть реализован в случаях, когда ответчиком по делу выступает иностранное лицо, которое в России никак не представлено и не имеет в России имушества, хотя, например, причинило на территории России вред истцу. Впрочем, и второй подход не свободен от недостатков. Если считать, что статьи 247 - 249 АПК РФ 2002 г. не только определягт посредством юрисдикционных привязок компетенцию государственных арбитражных судов в аспекте международной подсудности, но и содержат критерии разграничения внутритерриториальной подсудности, то тогда окажется, что иностранные лица в ряде случаев будут оказываться в более благоприятном положении, нежели российские лица, при обращении с исками в российские государственные арбитражные суды. Так, на основании подпункта 1 статьи 247 иностранные лица будут иметь право обрашаться в любой суд по месту нахождения имущества ответчика-российского лица, а не в суд по месту его нахождения, как это предписано для российских истцов.

Соответственно, для недопушения этого надлежит считать, что статьи 247 - 249 АПК РФ 2002 г. содержат критерии разграничения внутритерриториальной подсудности только для тех случаев, когда ответчиками являются иностранные лица (за исключением подпункта 8 пункта 1 статьи 247 АПК РФ 2002 г. («заявитель по делу об установлении факта, имеючего юридическое значение, указывает на наличие этого факта на территории Российской Федерации»), очевидным образом рассчитанного на применение к иностранным лицам как заявителям). Такое толкование, впрочем, не стыкуется с подпунктом 1 пункта 1 статьи 247 АПК РФ 2002 г. 
(«ответчик находится или прожсивает на территории Российской Федерачии либо на территории Российской Федерачии находится имущество ответчика»): если под ответчиком понимать только иностранное лицо, то как оно может находиться или проживать на территории России? Если это лицо в России находится или проживает, то его статус как иностранного может вызывать сомнения.

Заметим попутно, что формулировки статей 247 - 249 АПК РФ 2002 г. являются не вполне удовлетворительными и с точки зрения других проблем международного гражданского процесса. Вызывает много вопросов, помимо поставленных выше, и их соотношение со статьями 35 - 38 АПК РФ 2002 г. Впрочем, это уже тема для отдельного исследования.

Сейчас же можно сделать следующий вывод: если принять тот подход, что статьи 247 - 249 АПК РФ 2002 г. содержат критерии разграничения внутритерриториальной подсудности для тех случаев, когда ответчиками являются иностранные лица, то АПК РФ 2002 г. надлежит признать совпадающим с ГПК РСФСР в части положений о том, что иск к юридическому лицу предъявляется по месту нахождения органа или имушества юридического лица (статья 117 ГПК РСФСР) и что иски о возмещении вреда, причиненного имуществу гражданина или юридического лица, могут предъявляться также по месту причинения вреда (статья 118 ГПК РСФСР).

Отсюда следует, что процессуальный закон, регулируюший деятельность судов общей юрисдикции, предусматривает только два правила по поводу юрисдикционных привязок, отсутствуюшие в АПК РФ: иск к ответчику, не имеюшему в СССР (т.е. в России) места жительства, может быть предъявлен по последнему известному месту его жительства в России (статья 118 ГПК РСФСР); гражданский иск, вытекающий из уголовного дела, подлежит рассмотрению в суде по месту совершения преступления (пункт 10 статьи 31 и пункт 1 статьи 32 Уголовно-процессуального кодекса РФ от 18 декабря 2001 г. № 174-Ф3). Вполне понятно, что в каждом из этих двух случаев иск может касаться вопросов предпринимательского характера, которые, по общему правилу, являются подведомственными государственным арбитражным судам. По этому поводу отметим также, что слова «гражданский иск» в Уголовно- 
процессуальном кодексе РФ не могут пониматься как относящиеся исключительно к искам непредпринимательского характера.

Итак, на основании всего вышеизложенного можно утверждать, что возможны только две ситуации, когда суд общей юрисдикции в силу только одного статуса лица как иностранного субъекта сможет, основываясь на аспекте международной подсудности, претендовать на наличие у него компетенции разрешать предпринимательский спор с участием такого иностранного лица: если ответчик ранее имел в России место жительства, но уже не имеет; если иск, вытекаюший из уголовного дела, подлежит рассмотрению в суде по месту совершения преступления. Основанием для таких претензий будет являться то, что процессуальный закон, регулирующий деятельность судов общей юрисдикции, определяет их компетенцию рассмотреть такой спор, причем определяет не с точки зрения разграничения внутритерриториальной подсудности, а именно с точки зрения международной подсудности.

Будут ли юридически обоснованными такие претензии суда общей юрисдикции?

Признание допустимости рассмотрения судом общей юрисдикции иска, заявляемого в уголовном процессе, даже если он касается вопросов предпринимательского характера, не может встречать каких-либо возражений, причем даже безотносительно к тому, имеет ли связанное с таким иском лицо статус иностранного. Коль скоро закон дозволяет предъявлять иск как в уголовном процессе, так и помимо него, то право выбора должно принадлежать заинтересованному лицу. Если оно предпочитает заявить его в уголовном процессе, то рассматривать его может только суд общей юрисдикции, а не арбитражный суд, невзирая на природу требований в таком иске.

Соответственно, оказывается, что остался только один предмет для анализа: ситуация с ответчиком, который ранее имел в России место жительства, но уже не имеет. Само собой разумеется, что речь идет об ответчике - физическом лице, поскольку юридическое лицо иметь место жительства не может. При этом вопрос о компетенции суда общей юрисдикции рассматривать иск предпринимательского характера к такому ответчику может быть с равным успехом поставлен как в случае, когда иностранное лицо является истцом, заявляющим иск к такому ответчику, так и в слу- 
чае, когда иностранное лицо само является таким ответчиком. В первом случае иностранное лицо может заявлять о необходимости судебной защиты его прав в условиях, когда процессуальный закон допускает компетенцию суда общей юрисдикции, хотя требования и носят предпринимательский характер. В самом деле, в государственный арбитражный суд такой иск заявлен быть не может: хотя он ему и подведомствен, но с точки зрения международной подсудности - неподсуден. Во втором случае заявлять о необходимости судебной защиты свонх прав со ссылкой на те же аргументы может российский истец против иностранного физического лица-ответчика.

Так что же должно иметь приоритет: подведомственность или подсудность? По обшему правилу, первенство должно признаваться за первой. Но было бы справедливым отказать в судебной зашите прав со ссылкой на неподведомственность спора в условиях, когда: 1) суд общей юрисдикции признается законом компетентным с точки зрёния международной подсудности рассматривать спор?; 2) суды общей юрисдикции могут рассматривать непредпринимательские споры гражданского характера, тогда как предпринимательский спор, вопрос о передаче которого в такой суд поставлен, также носит гражданский характер?; 3) суды обшей юрисдикции до момента вступления в силу АПК РФ 2002 г. рассматривали предпринимательские споры с участием иностранных Лиц?

Думается, что в таких условиях подобный отказ был бы недопустим. Еще менее допустимым он является в свете пункта 1 статьи 46 Конституции РФ («Кажюдому гарантируетсл судебная заицит его прав и свобод») и пункта 1 ее же статьи 47 («Hикmо не может быть лииен права на рассмотрение его дела в том суде и тем судьей, к подсудности которых оно отнесено законом»). Хотя в последней норме под «подсудностью» следует все же понимать не тольқо внутритерриториальную и международную подсудность, но так же и подведомственность, ссылка на буквальное значение этого термина в какой-то мере может учитываться при решении рассматриваемой проблемы.

Таким образом, ситуация, когда суд общей юрисдикции в силу только одного статуса лица как иностранного субъекта может, основываясь на аспекте международной подсудности, правомер- 
но претендовать на наличие у него компетенции разрешать предпринимательский спор с участием такого иностранного лица, действительно возможна, но только в одном единственном случае: когда ответчик ранее имел в России место жительства, но уже не имеет. Иными словами, иск предпринимательского характера к ответчику, являющемуся иностранным физическим лицом, может быть заявлен в России не в государственный арбитражный суд, а в суд общей юрисдикции, если ранее такой ответчик имел в России место жительства.

Нельзя исключать, что ситуация изменится, когда будет принят новый ГПК РФ: либо только что указанный случай станет невозможным, либо количество подобных случаев увеличится. Все желающие могут ознакомиться с проектом ГПК РФ ${ }^{16}$ и попытаться определить соответствующие перспективы.

На основании сказанного можно также сделать следующий любопытный вывод: при разработке и принятии АПК РФ 2002 г. было сделано почти все возможное, чтобы не допустить конкурирующей юрисдикции между государственными арбитражными судами и судами обшей юрисдикции. Вероятно, учитывался и аспект, связанный с внутритерриториальной и даже международной подсудностью, для того, чтобы у судов общей юрисдикции не имелось возможности ссылаться на правила о подсудности в обоснование своей компетенции рассматривать споры предпринимательского характера: для этого в АПК РФ 2002 г. были продублированы все нормы ГПК РСФСР о подсудности, за исключением только что рассмотренной. Видимо, противостояние между этими судами достигло очень серьезной степени накала. Впрочем, вовсе не обязательно, что аспект международной подсудности принимался во внимание: в ГПК РСФСР нормы о подсудности служат как дпя целей внутритерриториального разграничения подсудности, так и международного.

${ }^{16}$ Внесен на рассмотрение Государственной Думы Федерального Собрания РФ Верховным Судом РФ. Постановлением Государственной Думы РФ от 14 июня 2001 г. № 1635-III ГД проскт этого кодскса принят в первом чтении (Собрание законодатсльства РФ. - 2001. - № 26. - СТ. 2627). Постановлением Государствснной Думы РФ от 26 июня 2002 г. № 2930-III ГД этот проект принят во втором чтении (Там же. - 2002. - № 27. - СТ. 2656). С текстом данного проекта можно ознакомиться в электронной справочной правовой системе «Гарант». 
И последнее. Выше рассматривался вопрос о соотношении института подведомственности с институтом международной подсудности применительно к компетенции судов обшей юрисдикции рассматривать споры предпринимательского характера с участием иностранных лиц, и было показано, что институт международной подсудности может влиять на наличие у суда общей юрисдикции права рассмотреть спор, хотя бы даже по общему правилу он был ему неподведомствен. Соответственно, если имеются сомнения по поводу того, подведомствен ли спор суду обшей юрисдикции, то ссылки на институт международной подсудности могут являться доводами в пользу наличия у суда права рассмотреть такой спор. А то, что сомнения по поводу того, подведомствен ли тот или иной спор суду общей юрисдикции, будут в дальнейшем появляться с неизбежностью, - бесспорно. Хотя при разработке и принятии АПК РФ 2002 г. было сделано почти все возможное, чтобы не допустить конкурирующей юрисдикции между государственными арбитражными судами и судами общей юрисдикции, все же пререкания между такими судами по поводу подведомственности споров возникать будут. Как уже говорилось, между новым АПК РФ 2002 г. и старым ГПК РСФСР в этом плане имеются некоторые нестыковки, а проблемы толкования положений этих нормативных актов могут оказаться настолько запутанными, что обрашение к правилам Федерального закона от 24 июля 2002 г. № 96-Ф3 «О введении в действие Арбитражного процессуального кодекса Российской Федерации» не окажется панацеей. Кроме того, продолжает действовать статья 28 ГПК РСФСР в редакции 1992 г. (обусловленной созданием системы государственных арбитражных судов): «При объедипении нескольких свлзаниых межсду собой требований, из которых одни подведомственны суду, а другие - арбитражсиому суду, все требования подлежсат рассмотренио в суде». Обращает на себя внимание то, что в этой норме ничего не говорится по поводу того, что для рассмотрения дела в суде общей юрисдикции необходима невозможность разъединения таких требований. В этой связи нельзя не сказать о том, что статья 22 упомянутого выше проекта ГПК РФ устанавливает: «При обрацении в суд с заявлением, содержащим несколько связаниых между собой требований, из которых одни подведомственни суду общей юрисдикции, другие - арбитражному суду, если разделение требований 
певозможсио, дело подлежсит рассмотрению в суде общей юрисдикцuu.

В случае если возможсно разделение требований, судья выносит определение о принятии требований, подведомственных суду, и об отказе в принятии требований, подведомственных арбитражному суду".

Вряд ли норму статьи 28 ГПК РСФСР можно считать противоречащей Федеральному закону от 24 июля 2002 г. № 96-Ф3 «О введении в действие Арбитражного процессуального кодекса Российской Федерации», ввиду чего она является действующей в полной мере. В таких условиях возможности для судов общей юрисдикции рассматривать споры предпринимательского характера с участием иностранных лиц расширяются, причем уже без необходимости обращения к институту международной подсудности. Ссылки же на последний в таких случаях могут служить в качестве дополнительных доводов о наличии у суда общей юрисдикции компетенции рассматривать спор. 